\title{
The Body Responds
}

\section{Emma Green and Margot Solomon}

\author{
Department of Psychotherapy, Auckland University of Technology, \\ AUCKLAND, NEW ZEALAND
}

\begin{abstract}
The first author uses a hermeneutic approach to reflect on her somatic experiences with clients diagnosed with Anorexia Nervosa. Using poetry, imagery, and metaphor, as well as understandings drawn from the psychodynamic literature, she attempts to convey something of the nature of her journey towards making sense of her experiences. The second author was the supervisor of the first author's dissertation, from which this article arose.
\end{abstract}

\section{Whakarāpopotonga}

He whakaaturanga whakamārama te huarahi whāia e te kaituhi hai whakaaroarohanga ake i ōna wheako tangata mai i ngā kiritaki kua whakatauhia he Whakatiki Harukiruki. Ka whakamahia e ia te toi kupu, whakaata, me te kupu whakarite, me ngā mātauranga tangohia mai i ngā tuhinga taipana hinengaro, ka whakamātau ki te whakamōhio i te āhua o tāna hīkoi ki te whai mātauranga whakatairongo i ōna wheako. Ko te kaituhi tuarua te kaihautū o te tuhinga a te kaituhi tuatahi, te papa o te aranga mai o tēnei pepa.

Keywords: hermeneutic; anorexia nervosa; psychotherapy; experience; eating disorder; Gadamer

\section{My Starting Point}

I (Emma) became interested in this topic whilst working in two different eating disorders treatment settings (one residential, one out-patient) during my clinical training as a psychotherapist. I found that many of my clients had complex, often disturbed relationships with their bodies and with food. The anorexic client is renowned for evoking strong emotional responses in treating clinicians, and family members, ranging from "utter frustration, anger and rejection to admiration and saviour fantasies" (van Furth, 1998, p. 320). These clients have tended to evoke strong responses in me, both physically and emotionally, and these became the starting point for my dissertation, a hermeneutic literature review exploring therapists' experiences with the anorexic client (Green, 2016).

Green, E. and Solomon, M. (2020). The Body Responds. Ata: Journal of Psychotherapy Aotearoa New Zealand, 24(1), 29-42.https://doi.org/ajpanz.2020.03 
This paper is inspired by, and draws from, my dissertation but is not a summary. It is perhaps more accurate to say that this paper offers some reflections on learnings from the dissertation process and how my clinical work has been shaped by my growing understanding of hermeneutics. Whilst I draw on some of the literary sources that feature in my dissertation, this paper is not a comprehensive review of that literature; rather, I hope to offer the reader a thoughtful exploration of an aspect of my work with this client group stemming from my somatic countertransference.

\section{Thinking Hermeneutically}

Hermeneutics is concerned with interpretation. Gadamerian hermeneutics is concerned with the other, or the voice of the other and inviting the other into conversation (Gespräch). Increasingly I have come to think of this as a hermeneutic sensibility, a way of being in the world, such that we might speak of it as a way of attending, a way of listening, a way of being with the other in order that we might 'come to an understanding'. Although hermeneutics has its origins in the interpretation of texts as a methodology it has a much broader scope. Hermeneutics can clearly be applied to text but also other material which we might attempt to understand, such as human behavior, or in this case feelings and responses evoked by the other.

Using a hermeneutic approach means working to stay open to possible meanings, rather than rushing to make sense of, to form tidy, possibly premature, conclusions. Gadamer (1975/2013) states that "the hermeneutical task becomes itself a questioning of things" ( $p$. 281 ). In staying open, in laying ourselves open to the questioning, we must take care not to rely on our own "accidental fore-meanings" (p. $28_{1}$ ), that is to say, our own current understandings, or biases, that we necessarily bring to that which we are trying to understand. In staying open and questioning we must be prepared for the that which we are trying to understand to tell us something (p.282). For Gadamer the hermeneutic task, the hermenutical conversation, is an art, a dialogic art. We enter into a conversation or a dialogue with the text, or the other (p.376), and that conversation is "a process of coming to an understanding" (p. 403). As we dialogue with that which we are attempting to understand we question, and for Gadamer, "to question means to lay open, to place in the open" (pp. 375-376) for "questions always bring out the undetermined possibilities of a thing" (p. $\left.38_{3}\right)$. This is a process of "question and answer, giving and taking" (p.376) that brings change, extending our horizon, our way of seeing the world. In entering the dialogue, in reaching towards understanding, in opening ourselves to the other, we put ourselves at risk, we are "transformed into a communion in which we do not remain what we were" (p. 387 ). Through this process our own preconceptions, or biases, come to the fore; they come "into play so that the text's meaning can really be made to speak for us” (p. 415).

An anorexic body is not a written text, nor is what occurs in a clinical session; however, Gadamer states that we can think of all understanding as occurring in this way, so in this case my attempts to interpret and understand what is happening between therapist and client become part of the 'text' under consideration. My own thoughts and fore-meanings become part of what awakens, and thereby determines, the meanings found, thus bringing them into play, and putting them at risk, making "one's own what the text says" (p. 406) which Gadamer refers to as the "fusion of horizons" (p. 406). 


\section{Self-as-Crucible}

In my work with this client group I often experience more visceral, and more frequent, body countertransference. As I have mentioned this became the impetus for my dissertation research but increasingly a hermeneutic approach felt congruent with my desire to bring myself, in terms of my reflexivity, and my self-understandings or fore-meanings, to my thinking and my clinical practice.

A hermeneutic way of thinking, reading and researching leads the researcher to incline towards "a very attentive attunement to 'thinking' and listening to how the texts speak" (Smythe et al, 2008, p.1389). Correspondingly, a hermeneutic way of thinking might lead us to incline towards our clients in the same way, as a particular way of attending and attuning to our clients. There is an unfolding process, as the researcher, or therapist, moves back and forth between the whole (the object of comprehension) and the parts (that which makes up what is to be understood) in the hermeneutic circle of understanding. Smythe and colleagues (2008) suggest that the process is one of "letting come" rather than working out (p. 1391). This careful listening, attunement and reflexivity towards the texts, or in this case what was unfolding (and unspoken) in my relationship with this client, is well suited to my practice as a psychotherapist. I sit with clients as each session unfolds before us, attempting to attune myself to, and make sense of, what is happening between us in the here and now using my capacity for reverie (Bion, 1962/2014, p. 303). Ogden (1997), referencing Bion, describes using reverie to discern what is "most alive" (p. 719) in the therapeutic milieu with each client. I feel myself attempting to discern that which is most alive in the sessions with my clients, or in terms of Bion's use of the term reverie, finding the $\mathrm{L}$ (love) connection (Bion, 1962/2014, p. 303).

In bringing my reflexivity to the dissertation research and in paying careful attention to my own process with clients, it was necessary to reflect on my changing self-understandings, on how I am changed by what I encounter, and am changed by the process of coming to an understanding (Gadamer, 1975/2013). As Donna Orange suggests, quoting Davey, "as clinicians we place ourselves at risk and allow the other to make an impact on us, to teach us, to challenge our preconceptions and habitual ways of being, to change us for their sake" (2011, p. 23). In reflecting here on my clinical work with a particular client I am engaging in a cycle of thinking, reading, writing and reflection, although the client's body, my body, and the feelings evoked in me as I sit with her become part of the 'text' being questioned, along with my process notes and, over time, poetry that I would write about her. As I have developed in my clinical practice, I often find myself jotting down lines of poetry alongside my clinical notes. I find this helps my thinking and that poetical thinking can open up surprising new way of seeing and thinking about things (Freeman, 2017). I have come to think about this process as one of self-as-crucible, whereby new, emerging thought forms, those most alive, are encountered and can be incorporated into one's thinking, writing and work. A hermeneutic process does not seek to arrive at what might be 'known' or discovered as objective. Rather, the thoughts encountered are a reflection of, or an amplification of, that "which is always/already drawn from all of my experiences and conversations" (Smythe et al, 2008, p. 1391). 


\section{Viscerality}

During the course of regular twice-weekly psychotherapy with a client diagnosed with anorexia I would sometimes experience a sharp, tingling sensation in my breasts at the end of some of our sessions. This would be accompanied by what I can only describe as a rush of deep warmth and affection towards the client. At the time, as a training psychotherapist, I felt ill-prepared for such physical responses to my clients. I have children who I breastfed, and so my 'knowing' (fore-understanding) about this experience was as a 'let down' reflex. This reflex happens in the breastfeeding mother's body. As mother and infant prepare for a feed the baby draws the breast tissue into its mouth, stimulating nerves in the breast and causing the release of hormones in the mother's system. Prolactin, known as the mothering hormone, stimulates the milk-producing tissues in the mother's breasts. Prolactin is also thought to support maternal behaviour, encouraging the mother to respond to her infant. Oxytocin, known as the hormone of love, calm and connection, triggers the breast to push out, or 'let down' the milk. In the mother-infant pair this typically happens close to the beginning of the breastfeed, although it can happen multiple times in any feed. These hormones reach the infant through the mother's milk, acting to promote feelings of calm and relaxation in the dyad (WHO, 2009).

The 'let down' reflex is typically initiated by the infant through its stimulation of the breast; however, it can also be initiated by the mother's thinking of the infant, her mental act of holding the baby in mind, by her hearing her baby's cries, or seeing, smelling or touching her baby (WHO, 2009). Oxytocin is the hormone of love, attachment and bonding, and so we might theorise that the mother's love and connection with her baby, even as she thinks about her baby, stimulates her body to anticipate and respond to her infant's needs for closeness and food. A fuller exploration of the complex nature of this interaction is beyond the scope of this article; however, I describe it briefly to give the reader some context.

What did this sensation mean? Was I abnormal? It was happening in my body but it hadn't happened with other clients, so it seemed to relate to this client in particular. If I hadn't had a breastfeeding experience how might I have thought about these feelings? Given that a woman's breasts are typically highly sexualised in Western culture, some women are confused when they experience these feelings in a breastfeeding situation with their infant. In deciding whether to raise this experience in supervision I was aware of my sense of shame and awkwardness, to bring my body (such a sexualised part of my body), and such an intimate experience, into what was a fairly new supervisory relationship.

I thought about my physical response to her as perhaps connected with her will to live, part of my body, or my psyche, responding to the part of her that wanted to thrive, despite all the evidence to the contrary, such as her many life-denying behaviours, for example extreme restriction of food, purging anything she did eat, and a brutal exercise regime.

\section{Making Sense}

My experience with this client could be thought about as an unconscious communication from the client (Schore \& Schore, 2008), manifesting as an embodied countertransference (Field, 1989; Totton, 2010) in my body, perhaps a representation of her 'feeding difficulty' or her 'failure to thrive'. 
Samuels describes countertransference as a "physical, actual, material, sensual expression in the [therapist] of something of the patient's inner world" (19\$5, p. 199). Wooley goes further, including "all the therapist's responses to the [client], occurring at various levels of awareness, to all of the [client's] verbal and nonverbal communications” (1991, p. 255).

Perhaps the experience I have described above represented a pull from the client for me to feed her, her desire for connection, nourishment, and the nurturing I had to offer that could not be taken advantage of during the session, but only too late, at the end of our time. Perhaps this feeling could take hold in my body because it reflected my own desire to feed her, metaphorically speaking, to nourish and strengthen her diminished frame. Certainly I wanted, sometimes painfully, for her to get something from our time, for her to be able to 'take in' something. Perhaps the feeling represented my own wish for her to thrive in the therapy, that I might successfully 'feed' her, that I would be a good therapist, or a good mother. That I could save her from herself.

Lemma (2016) has suggested that body or somatic countertransference will be a feature of the therapist's experience when the client has difficulties in symbolising their inner world. Projecting into the therapist's body becomes a way to express thought. Thus it is possible to consider the feeling in my breasts as a form of projective identification, originating in the client, and projected into me, as the therapist. Projective identification can be thought about as a "very primitive means of communication ... that permeates the core of many psychotherapeutic treatments ... and can produce intense countertransference reactions" (Waska, 1999, n.p.). Schore and Schore outline a neuropsychological mechanism by which this takes place, where "nonverbal affective and thereby mind/body communications are expressions of the right brain" (2008, p. 15). The right brain of the client implicitly communicates with the right brain of the therapist, and vice versa. These "intersubjective transactions lie at the core of the therapeutic relationship" (Schore and Schore, 2008, p. 14), and the infant/caregiver relationship.

Segal (1973) has suggested that just as unwanted or disowned parts of the self might be projected in order to get rid of them, good parts might be projected in order to "keep [them] safe from what is felt to be overwhelming badness inside” (p. 26). Perhaps the client was attempting to protect an endangered part of herself, her own capacity to nourish and nurture. Perhaps this nascent part, as yet without much form, needed to be nurtured and protected in order to come more fully into being. By 'giving' it to me for safekeeping she protects this part of herself from the ravages of anorexia. We were able to talk about the ways in which she felt taken over by the 'anorexic part' of her and she could acknowledge that the other parts, those that might 'fight back' were very small and, at that time, incapable.

\section{Overlooking the Body}

Orbach (2004) has written that in privileging language, and the mind, we all too often overlook the body. Clients' somatic symptoms are considered to emanate from troubled minds, similarly with the therapist's body countertransferences, the inference is that they have a psychic origin. Orbach warns "we can unintentionally ignore what the body is capable of doing to the mind or what the body discloses about the body per se" (p.142). She challenges the therapist to consider the physical sensations they experience, not just in terms of 
revealing information about the client's psyche, but in terms of "the physical meanings that can be made of them" (p. 143). Orbach cites several examples of visceral bodily sensations (her own and reported to her), in response to being with clients, in order to "extend some of the taken for granted supremacy of the mind" (p.145). She encourages us to consider how the body is formed in relationship, like the psyche, and how the therapist's body can express the "relational complexities between the two people in the room" (p.149). One such example is a case reported to her in which a therapist "working with a regressed patient felt the let down reflex in her breasts". This happened repeatedly over an extended period of thriceweekly psychotherapy, despite the therapist in question not having breastfed for over 15 years. The therapist feels the patient's request or demand for physical provision, and there is "something quite literal and concrete about [the] patient's need for a physical feed that this stimulation of her reflex brought into the therapy" (p. 145). I have thought about the ways my client might have needed physical provision, both for her ravaged body and for the parts of her psyche trying to come into being.

\section{The Whiteout}

At other times in our sessions I would experience a peculiar dizzying sensation that was very disorienting. It felt a little like something was being pushed into or onto my head from all sides and it made it very difficult to think. I would occasionally have a sense of 'coming to', finding myself looking out into the garden outside, not completely aware of where I had 'been'. This fuzzy-headed feeling reminded me of Lawrence's (2008) writing about the 'whiteout'. She uses the term as a metaphor for the anorexic's inner space, after a client describes a dream to her where everything is painted white. She theorises the client's need to make the therapist redundant and useless, linking the whiteout to her client's "objectless world" (p. 44). I could relate to experiences of feeling useless and redundant with this client. Lawrence suggests the anorexic client is seeking oneness, or merger, and it is this oneness Lawrence describes as, "featureless ... a barren landscape, a white room, an analyst without qualities" (p. 44). As though difference would be impossible to tolerate.

Winston (2009) writes that the anorexic client "evacuates feeling into the therapist rather than sharing it" (p. 82) so perhaps this dizzying sensation might be thought about as an example of this, possibly to get rid of an unwanted or unbearable feeling, but also potentially as communication, enabling me to understand something of her own experience, that difference (life, vitality or anything running counter to the anorexic script) would not or could not be tolerated. I wondered whether my somatic counter-transference could relate to a pull for merger, as infant and mother become one in the breastfeeding experience. Its arrival at the end of our sessions meant I felt redundant. My nurturing, my care, came too late and I was unable to 'feed' her just as my thinking in our sessions felt compromised.

Along with poetry I find imagery particularly helpful in stirring thinking when thinking has become stuck or difficult. Images resulting from the search term 'whiteout', such as the one above (Figure 1), evoke a palpable sense of the confusion, disorientation and lack of horizon that anyone who has ever experienced a whiteout will attest to. Looking at this image I can feel a sense of defeat, of the futility in trying to proceed. Just as the usual landmarks and visual cues by which we navigate and make sense of our physical world are 


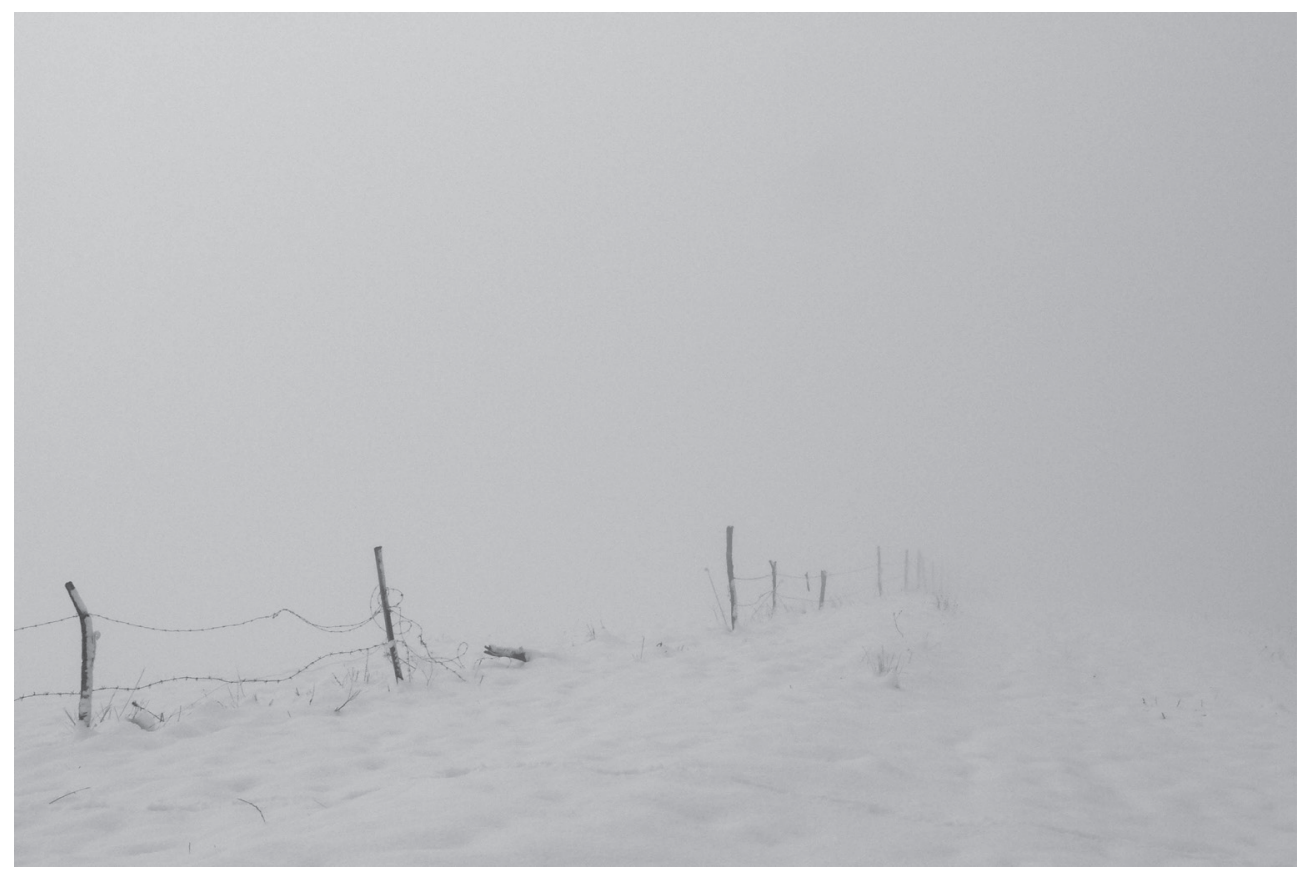

Figure 1 Whiteout. Copyright Miles Heller, Some Rights Reserved.

obliterated by the whiteout, so too in working with the anorexic client there is difficulty moving forwards, in thinking and navigating the relationship. Images like this came to form a sort of waking, bewildering dreamscape as I was writing my dissertation and in my thinking about this client.

\section{Keeping the Therapist Out}

Similar to the feelings of redundancy described above, both Williams (1997) and Willner (2002) describe the anorexic client's 'no entry defences'. This resonated with my own sense of being helpless to do anything, of being 'kept out', and my feelings of powerlessness. Wanting to give her a satisfactory, nourishing experience, but always being too late or not able to be 'used'. My experience of the 'no-entry' would occur during our many protracted silences wherein I frequently had the thought that a part of her hated me and my 'prying'. That my thinking (and my being) was an unwelcome intruder to be kept out at all costs. Several times I had the fantasy that part of her was silently screaming at me to "get out" and at the same time, a sense that I needed to stay present, gently waiting, letting her know I could be an ally, if the part of her that wanted to thrive was able to come forwards.

I have thought a great deal about this smaller part that might be tucked away, the desire to thrive and live, fight even, and how this part needs to be protected from the tyrannical part that threatens to destroy everything, the anorexia. Her survival then is an act of resistance, the part of her that perhaps reaches out to me, that I get to feel in my body, is like 
a member of the resistance forces. It is my job to find a way to make contact. We could think about this as smuggling messages back and forth (Lynch, 2018) in order to support the resistance. There is a focus on building an alliance, on engaging and supporting that (however small) part of her that wants to live. I have often reflected that it is impossible to negotiate with anorexia. Much like any tyrant its law is absolute and uncompromising and the best way to 'get through' is to find ways to 'go around'.

\section{Getting Lost in the Blizzard}

In a hermeneutic tangent, thinking about the whiteout brought to mind the writing of Parker J. Palmer. Palmer (2004) tells how farmers on the Great Plains, at the first sign of a blizzard, "would run a rope from the back door out to the barn. They all knew stories of people who had wandered off and been frozen to death, having lost sight of home in a whiteout while still in their own backyards" (p. 1). The whiteout had become a powerful metaphor informing how I thought about my own experiences with this client group. For the anorexic client, it is as if no-one has run the rope from the back door out to the barn and so in the therapy we are in danger of wandering off, losing sight of home. I saw my own fears of getting hopelessly and helplessly lost, and the aloneness, panic and desperation that could follow, and also how these might be expressed in my desire to do something, to provide sustenance. To lead her back to herself, to keep us both safe.

I came across this poem by William Stafford (1998):

\section{The WAY It Is}

There's a thread you follow. It goes among things that change. But it doesn't change.

People wonder about what you are pursuing.

You have to explain about the thread.

But it is hard for others to see.

While you hold it you can't get lost.

Tragedies happen; people get hurt

or die; and you suffer and get old.

Nothing you do can stop time's unfolding.

You don't ever let go of the thread.

This poem spoke to me on several levels. It made me think about the role of the therapist in helping the anorexic client find her own 'thread that doesn't change'. Her connection to herself, that will allow her to connect with the world, that she can hold on to so that she won't have such an intense fear of becoming lost in the blizzard of the whiteout as she begins to encounter the certainty that things must change in order for her to grow, physically and mentally. The poem also helped me think about the process of searching in the literature to try and make sense of my experience. I was trying to find my own thread, my way of navigating the world as a neophyte psychotherapist working with a challenging client population. I was also trying to find my own thread as researcher. Gadamer said those who express themselves and those who try to understand are 
connected by a common human consciousness, a thread that makes understanding possible (in Ray, 1994).

Part of this thread was my felt sense of my experiences with clients. Although things would inevitably change, I could hold onto this thread, learning to trust my intuition, with a secure starting point from which to venture out, and a base to return to.

\section{Finding Hope (When Hope is Lost)}

Bromberg suggests that the reason this client group is so difficult to work with is that "they deprive a therapist of what [s] he most counts on in order to sustain hope - a working relationship that will grow in depth and security as the work progresses" (2001, p. 893). The usual give and take in a relationship, a thread of connection perhaps, is absent, or at best minimal, with this client group (Bromberg, 2001). Similarly, Babits writes that the "difficult patient effectively 'kills off' all movement or direction, all sense of manifest hope" (2001, p. 342). Although not expressly talking about an experience with an anorexic client, Babits' writing gave me an appreciation for the need to be able to talk with these clients about the hopelessness that would inevitably pervade our work. He describes these potential moments as the "phoenix juncture ... a moment of symbolic death of hope within the treatment and the acknowledgment of this death by the therapist" (p. 343). Of course, there is "appropriate consideration to timing, dosage and other relevant clinical factors" (p. 343). The therapist's acknowledgment of the intense difficulty in maintaining hope "becomes a pathway to the possibility of reconnecting with the patient's embedded (frozen) sense of hopefulness" (p. 343). Babits' notion that there is a place of hopefulness that can be reached, in need of transformation from its frozen state, reminded me of Palmer's blizzard and the whiteout.

\section{Wanting to Feed the Client}

Since finishing my dissertation in 2016 I have continued to work with this client group. One of the things I have found helpful in bearing the feelings evoked in me is writing my own poetry, often jotting down lines in the margins of my notes. The poet Elizabeth Alexander once said that we are "each unto ourselves, inside of our heads" and that "we need language to reach across the void, to reach another human being" (Tippet, 2011). Reaching across the void is reminiscent of Palmer's rope tied to the back door. Whilst I agree with Alexander's words I am aware that many times, sitting with the anorexic client, there are no words and we sit in a weighty, sometimes tortured, silence. I am certain that this torture is, at times, felt by both myself and my clients, and that we are both trying our best to bear it. Alexander's idea of reaching across the void reminds me of my body's attempts to reach out, to be of use to my clients, perhaps when I can no longer bear wandering in the whiteout. The poem below was written several years after my dissertation was completed. Whiteout was inspired by a re-reading of my dissertation process journals whilst I found myself struggling with another client who has an eating disorder. The poem helped me reflect on my experiences of wanting to 'feed' the client with whom I began this writing and also serves as a way to think about those clients I am currently working with. 


\author{
WHITEOUT \\ We carry our empty \\ bellies \\ over silent, white \\ space \\ Longing to put down \\ this burden \\ I do not know which of us is more tired \\ Cold pressing into our \\ ears \\ hard to feel this \\ distance \\ The weight of our sitting, \\ our waiting
}

I do not know which of us will break first

And the shadow of your

death

across lifeless empty

time

Stretching, a no-man's land

littered with

I do not know how to reach you

Stubborn refusals

a body

wanting to fill you up

needing

to give you something.

Use me.

You do not know how

I include the poem here because as Gaston Bachelard says, "the image has touched the depths before it stirs the surface" (1969/1994 p.xiii), suggesting that the image or metaphor so readily available to us in the poem reaches us deeply, perhaps bypassing 'rational' thought, much like my client's communication to me. Or to put it another way, as researcher Laurel Richardson says, "lived experience is lived in a body, and poetic representations can touch us where we live, in our bodies" (1997, p. 143). So poetry, or poetic representation, provides me with a way to explore, to question, and to lay open my lived experience allowing me new ways of thinking. 


\section{Staying Open to The Body}

Psychoanalytic thought and psychotherapy have undoubtedly developed from within a patriarchal context. Having their roots in a socio-cultural-historical location when/where science and reason were seen to be the ultimate ends. Freud and his contemporaries were shaped by the cultural environment of their time, not only in terms of ways of thinking, and the increased value placed on freedom and tolerance, but also the increasing demands of the time for scientific rigour, empiricism and reductionism (Shapiro, 1996).

Critics have argued that psychoanalysis, and its progeny psychotherapy, is somewhat removed from the experience of the body (for example, Orbach, 2004; Shapiro, 1996) perhaps because psychoanalysis can fall into the mind/body split that pervades. There is a "tendency to order our experience hierarchically" and as therapists that tendency extends to the ways in which we "deeply privilege linguistic, narrative forms of communication" (Shapiro, 1996, p. 299). Staying open to the body, the client's body and my body, seemed vitally important to my understanding of my experiences with this, and other client groups, but also to my development as a psychotherapist and a hermeneutic researcher. To negate the body is surely to overlook a vast wealth of information.

I did not want to discount my own bodily experience in favour of an understanding that made sense of the anorexic predicament in a purely intrapsychic way. Nor did I want to rush to put language or meaning to my bodily experience. This is in essence Keats'(1817) concept of negative capability, that we strive to remain open and receptive, to be "capable of being in uncertainties, mysteries, doubts, without any irritable reaching after fact and reason" (1817/1970, p. 43). This capacity is of vital importance in both hermeneutic research and psychotherapy practice and is, to my mind, exactly what Gadamer tasks us with in exhorting us to lay ourselves open to the questions asked of us by the other (1975/2013, p.3 $\left.82-3 \delta_{3}\right)$.

I felt myself stretching to tolerate the "presence of the absence of certainty" (Boris, 1984, p. 441), beyond an understanding of myself-as-receiver and client-as-sender, towards the notion that what was happening between us was dynamic, alive and co-created, and perhaps not possible to fully understand. What happens between me and a particular client would perhaps not happen with that client and a different therapist. This thinking represents something of my 'discovery' of a two-person psychology (Mitchell and Aron,1999). Through my felt-sense (Gendlin, 1981) and my body, rather than theory, I was making space to think about my experience in different ways. The theories of intersubjectivity and right-brain to right-brain psychotherapy became a living, embodied experience (in both my body and the client's body). This intersubjective field is co-constructed by two individuals, "not just two minds but two bodies" (Schore and Schore, 2008, p. 15).

Staying open to the body (the therapist's and the client's) and staying open to potential meanings may challenge the tendency in us to irritably reach for fact and reason. Staying open to the body may challenge our privileging of mind over body, perhaps disturbing ideas instilled in us by our training. The openness required of us by a hermeneutic approach may place previous understandings or knowing at risk, potentially causing discomfort, but this is in essence Gadamer's exhortation that the hermeneut be radically undogmatic (1975/2013). Staying open to the body allows the possibility that we might learn, and be changed by what we learn, in new and surprising ways. 


\section{THE BODY RESPONDS}

\section{References}

Babits, M. (2001). The phoenix juncture: Exploring the dimension of hope in psychotherapy. Clinical Social Work Journal, 29(4), 341-350. https://doi.org/10.1023/A:1012263129391

Bachelard, G. (1969/1994). The poetics of space: The classic look at how we experience intimate places. M. Jonas (Trans). Boston, MA: Beacon Press.

Bion, W. R. (1962/2014). Learning from experience. In C. Mawson (Ed.), The complete works of W. R. Bion (Vol. IV, pp. 247-365). London, UK: Karnac.

Boris, H. N. (1984). On the treatment of Anorexia Nervosa. International Journal of Psycho-Analysis, 65, 435-442.

Bromberg, P. M. (2001). Treating patients with symptoms - and symptoms with patience: Reflections on shame, dissocation, and eating disorders. Psychoanalytic Dialogues, 11(6), 891-912. https://doi.org/10.1080/10481881109348650

Field, N. (1989). Listening with the body: An exploration in the countertransference. British Journal of Psychotherapy, 5 (4), 512-522. https://doi.org/10.1111/j.1752-0118.1989.tbo1110

Freeman, M. (2017). Modes of thinking for qualitative data analysis. New York, NY: Routledge.

Gadamer, H-. G. (1975/2013). Truth and Method. J. Weinsheimer and D. G. Marshall (Trans). New York, NY: Bloomsbury Academic.

Gendlin, E. T. (1981). Focusing. New York, NY: Bantam Books.

Green, E. (2016). The therapist's experience of working with the anorexic client: A hermeneutic literature review. Master's dissertation, Auckland University of Technology, Auckland, New Zealand. https://openrepository.aut.ac.nz/handle/10292/9869

Green, E. (2019). Whiteout. Previously unpublished.

Heller, M. (2016). Whiteout @ Some Rights Reserved. https://www.flickr.com/photos/ gian_s/23564143793/in/photolist-BUhoZg-5iCPcD-aspoCN-vUUgZ-Ns3RAL-4r31s2-BALns3af8nnJ-7bBodk-ap6gws-aF3KeZ-9CTzUF-ynnWY-9QupA-gXZDTX-ooyTUZ-7LwCco-jDQEDqeba8RY-A2kgS-7L27sm-7CxCLR-3r2Bw-b5hsw-6J2ewA-yegat-qXBVeZ-hYiC6q-5gyw2Uoz15xm-9VdrJX-tPPA9-euVBdo-joN5sW-a3s6xv-dTh9cJ-CRFf5T-jyqpb1-aGg18i-B5DdC5TkoSQ-R3j5HF-4duBwc-8JXmX4-9CqbFb-9Cqdyu-kmzsg-9jE2Mx-cqb41m-vMpDF

Lemma, A. (2016). Introduction to the practice of psychoanalytic psychotherapy. (2nd Ed.) Chichester, England: Wiley.

Keats, J. (1817/1970). [Letter to brothers George and Thomas Keats]. In R. Gittings (Ed.). The Letters of John Keats. Oxford, England: Oxford University Press.

Lawrence, M. (2008). The anorexic mind. London, England: Karnac Books.

Lynch, T. (2018). Radically open dialectical behaviour theray: Theory and practice for treating disorders of overcontrol. Oakland, CA: New Harbinger Publications.

Mitchell, S. A., and Aron, L. (1999). Relational psychoanalysis: The emergence of a tradition. Hillsdale, NJ: The Analytic Press.

Tippet, K. (2011). Words that Shimmer. Interview with Elizabeth Alexander. https://onbeing.org/ programs/elizabeth-alexander-words-that-shimmer/

Orange, D. (2011). The suffering stranger. New York, NY: Taylor \& Francis Group.

Orbach, S. (2004). What can we learn from the therapist's body? Attachment and Human Development, 6(2),141-150. https://doi.org/10.1080/14616730410001695349

Palmer, P. J. (2004). A hidden wholeness: The journey toward an undivided life. San Francisco, CA: Jossey-Bass. 
Ray, M. A. (1994). The richness of phenomenology: Philosophic, theoretic, and methodologic concerns. In J. M. Morse (Ed.), Critical issues in qualitative research methods. Thousand Oaks, CA: Sage Publications.

Samuels, A. (1985). Symbolic Dimensions of Eros in transference/countertransference. International Review of Psychoanalysis, 12.

Schore, J. R., and Schore, A. N. (2008). Modern attachment theory: The central role of affect regulation in development and treatment. Clinical Social Work Journal, 36, 9-20. https://doi. org/10.1007/s10615-007-0111-7

Segal, H. (1973). Introduction to the work of Melanie Klein. London, England: Karnac Books.

Shapiro, S. A. (1996). The embodied analyst in the Victorian consulting room. Gender and Psychoanalysis, 1, 297-232.

Smythe, E. A., Ironside, P. M., Sims, S. L., Swenson, M. M., and Spence, D. G. (2008). Doing Heideggerian hermeneutic research: A discussion paper. International Journal of Nursing Studies, 45, 1389-1397. https://doi.org/10.1016/j.ijnurstu.2007.09.005

Stafford, W. (1998). The way it is: New and selected poems. Minneapolis, MN: Graywolf Press.

Totton, N. (2010). Being, having, and becoming bodies. Body, Movement and Dance in Psychotherapy, 5(1), 21-30.

van Furth, E. F. (1998). The treatment of Anorexia Nervosa. In H. W. Hoek, J. L. Treasure, and M.A. Katzman (Eds.). Neurobiology in the Treatment of Eating Disorders (p. 315-330). Chichester, England: John Wiley \& Sons.

Williams, G. (1997). Reflections on some dynamics of eating disorders: 'No Entry' defences and foreign bodies. International Journal of Psychoanalysis, 78, 927-941.

Willner, A. (2002). Imperviousness in anorexia: The no-entry defence. Psychoanalytic Psychotherapy, 16, 125-141. https://doi.org/10.1080/14749730210129392.

Winston, A. P. (2009). Anorexia Nervosa and the psychotherapy of absence. British Journal of Psychotherapy, 25, 77-90. https://doi.org/10.1111/j.1752-0118.2008.01102

Wooley, S. C. (1991). Uses of countertransference in the treatment of eating disorders: A gender perspective. In C. L. Johnson (Ed.), Psychodynamic Theory and Treatment for Eating Disorders (p. 245-294). New York, NY: Guilford Press.

World Health Organization (2009). Infant and Young Child Feeding: Model Chapter for Textbooks for Medical Students and Allied Health Professionals. Geneva: World Health Organization. https:// www.ncbi.nlm.nih.gov/books/NBK148965/

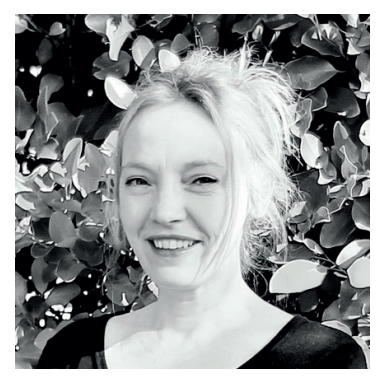

Emma Green is a registered psychotherapist in private practice and is currently enrolled in a PhD program at the Auckland University of Technology. Contact details: The Psychotherapy Centre, 300 Great South Road, Greenlane, Auckland 1051. Email: emmagreentherapy@gmail.com 


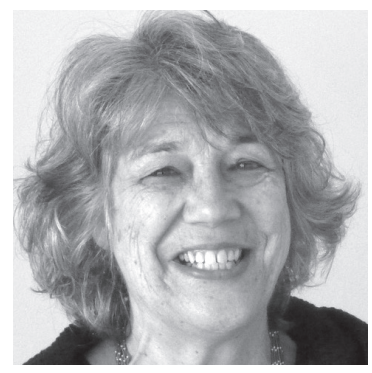

Margot Solomon is a senior lecturer and Postgraduate Programme Leader in Advanced Psychotherapy Practice at the Auckland University of Technology. She has a small private practice in psychoanalytic psychotherapy and group analysis. Email: margot.solomon@aut.ac.nz 